\title{
African Humanities and the Paradox of Western Education in Ghana
}

\author{
Philip Kwadwo Okyere' ${ }^{1}$ \\ 1 Mfantsipim School, Cape Coast - Ghana.
}

\begin{abstract}
The pre-colonial era of Africa was characterized, among other things, by a traditional or informal system of education. Some of the emphases of traditional education were (and still are) Africans' delight, expression and appropriation of their beliefs, values, precepts and ideals. Despite these laudable emphases, the traditional system of education is characterized by some scholars as lacking a formal or systemized structure of knowledge production. Moreover, the post-colonial debates on the influence of Western education in Africa in general and Ghana, in particular, are conspicuously silent on Western education's role in gradually altering the economic ideology of Ghana from a mixed and socialist economy to a capitalist mode of production. Using secondary data sources, this paper argues that the traditional system of education was (and still is) somehow structured or systemized almost as the formal or Western education. It also contends that Western education is gradually spearheading a paradigmatic shift in Ghana's economic system from mixed economy to capitalism. It further maintains that recourse to African humanities would mitigate the unbridled effects of capitalism in Ghana.
\end{abstract}

Correspondence

Philip Kwadwo Okyere

Email: philipkokyere@yahoo.com

Publication History

Received 5th August, 2021

Accepted 14th October, 2021

Published online 25th October, 2021

Keywords: African humanities, Western education, traditional education, economic system.

\section{INTRODUCTION}

There is actually no scarcity or dearth of scholarly discourse on African humanities (the values of respect, godliness, honour, hospitality, gratitude, national pride, aesthetics, hard work, etc.) and Western education in Africa or Ghana. The place and relevance of the African humanities in "remapping the fabric of the African self" has been underscored by Augustine Nwoye. ${ }^{1}$ Definitions of education have not escaped the intellectual gaze of J.S. Farrant ${ }^{2}$ and Nancino-Brown and Oke Brown. ${ }^{3}$ These scholars generally agree that education is a process through which an individual develops an understanding of a wide range of subject areas and the ability to think critically. Education thus promotes the development of the individual and his or her community. The viability of education in promoting development in sub-Saharan Africa has engaged the scholarly attention of Rose B. Folson. ${ }^{4}$ Moreover, it is insightful to point out that transported and adopted paradigms of Ghana's second cycle school system and their ramifications with respect to progress have been scholarly articulated in

\footnotetext{
1 Augustine Nwoye, "Remapping the Fabric of the African Self: A Synoptic Theory", Dialectical Anthropology 30 (2006), 119146, accessed May 6, 2015.http://www.jstor.org/stable/29790757

2 J. S. Farrant, Principles and Practice of Education $\left(2^{\text {nd }}\right)$ (Singapore: Longman, 1980).

Nancino Brown and Oke F. Brown, An Introduction to Methods of Teaching (London: Macmillan Publishers, 1982).

4 Rose B. Folson, "Educational Viability and Development: A Sub-Saharan Experience" The Journal of Educational Thought (JET) 40 (2006), 75-94.
} 
a study done by Hubert O. Quist. ${ }^{5}$

Some scholars are also of the view that the development of the European school system in Africa and Ghana, in particular, is paradoxical. In one sense, it is believed that Western education has debilitated the Ghanaian's previously cherished religio-cultural identity. In another sense, western education is perceived to have helped Ghanaians to develop some of their potentials. These issues have received considerable scholarly attention. ${ }^{6}$ Thus even though the Western style of training helps individuals by preserving and transforming their culture, ${ }^{7}$ it is certainly not without limitations. This is hardly disputed. But this article contends that the scholars whose works have been reviewed so far in this paper, to the best of the author's knowledge, have certainly not exhausted the discourse on the paradoxical orientation of Western education in Ghana. There are still some aspects not yet touched. That is precisely the focus of the paper.

To what extent, then, is the development of Western education in Ghana a paradox? This article attempts a response to this central question by first arguing that despite the laudable emphases of the traditional system of education in pre-colonial Africa, the traditional system of education or education in pre-colonial Africa is erroneously characterized by some scholars as lacking a formal or systemized structure of knowledge production. Moreover, the article contends that some of the post-colonial debates on the influence of Western education in Africa in general and Ghana in particular are conspicuously silent on Western education's role in gradually changing the economic ideology of Ghana from a mixed and socialist economy to capitalist mode of production. ${ }^{8}$ The article concludes with the place and relevance of African humanities in responding to the paradoxical issues that emerge in the debate.

\section{METHODOLOGY}

This article used the documentary research method in assembling the relevant pieces of information. Monageng Mogalakwe asserts that in the documentary research method, the researcher assembles and studies relevant literature that pertain to the problem or the subject matter under investigation. ${ }^{9}$ The benefits of the documentary approach cannot be overemphasized. It is sometimes preferred to the other known data gathering methods such as questionnaires and focused group discussions.

This method was deemed useful in this paper because the information about African humanities and Western education in Ghana could be found in documents. The novelty, however, is that the available pieces of information, to the best of the author's knowledge, have been assembled, organized and presented in the context of the paradoxical nature of Western education in Ghana and the relevance of African humanities in addressing the issues arising from the debate.

Moreover, the documentary research method was used to ensure that the pieces of evidence in the paper were authentic, credible, representative and meaningful. ${ }^{10}$ Authenticity in this context refers to the genuineness of the evidence as having flowed from implacable sources. Credibility points to the typical nature of the evidence and its reliability. Representative indicates the appreciation of the evidence as representing the entire materials or literature consulted. Meaningfulness has implications for the comprehensibility and clarity of the evidence gathered. ${ }^{11}$

\footnotetext{
5 Hubert. O. Quist, "Transferred and Adapted Models of Secondary Education in Ghana: What Implications for Development", International Review of Education 49 (2003),411-431, accessed May 6, 2015. http://www.jstor.org/stable/3445308

6 Jacob K. Olupona, “African Humanity Matters: Religious Creativity and Africa's World Encounters”, in Gordon S.K. Adika, George Ossom-Batsa and Helen Yitah (eds.) New Perspectives on African Humanity: Beliefs, Values and Atristic Expression (Accra: Adwinsa Publications (Gh) Ltd., 2014), pp. 1-17. See also Nana Kobina Nketsia V. African Culture in Governance and Development: The Ghanaian Paradigm (Cape Coast: UCC Press, 2013), Joseph Kingsley Aboagye, Historical and Philosophical Foundations of Education in Ghana (Winneba: Department of Basic Education, University of Education, Winneba, 2002). Judith Hama, The School Curriculum: A Tool for Education \& National Development (Ghana: Step Publishers, 2004).

8 H.O.A McWilliam and Kwamena-Poh, The Development of Education in Ghana (new edition) (London: Longman Group Ltd.1975). See also C.O. Abosi and Brookman-Amissah Introduction to Education in Ghana, (Accra: Sedco, 1992), Aboagye, Historical and Philosophical Foundations of Education in Ghana.

9 Monageng Mogalakwe, "The Documentary Research Method - Using Documentary Sources in Social Research", Eastern Africa Social Science Research Review. 25 (2009), 43-58, accessed August 21, 2014.

http://musejhu.edu/journals/eas/summary/v025/25.1.mogalakwe.html DOI: 10.1353/eas.0.0006

10 Mogalakwe, "The Documentary Research Method," 53.

11 Mogalakwe, "The Documentary Research Method," 53.
} 


\section{Theoretical framework}

Writing on "Social Sciences as Imperialism", Claude Ake presents Eurocentric Teleologism as one of "the general problems of methodological and ideological bias in Western social sciences'. ${ }^{12}$ The strong influence of teleological thinking in Western social science, in the opinion of Ake, is as a result of the works of great Western thinkers of classical and medieval periods such as Herbert Spencer, August Comte, Emil Durkheim, Max Weber, Karl Marx, Plato, Aristotle, Aquinas, St. Augustine, etc. The teleologism of these scholars "was linked to a developmental or historicist analysis of society such that they saw society as moving through two or more stages from a less desirable state of being to a more desirable one... Thus for Aristotle, the telos ${ }^{13}$ is the essence so that things are not what they seem and must be understood in all the contradictions inherent in their straining to realize their potentialities." 14

Eurocentric Teleologism underscores European social scientists' impression that the ultimate purpose of all other societies is to be like the West. Against this backdrop, "when Western scholars turned their attention to the study of Africa and other [Two-Thirds] world regions, the comparative studies which emerged presented the [Two-Thirds] world as approximations of typologies at the lower end of a developmental continuum, and presented Western societies as approximations of typologies at the higher and advanced stages of the same development continuum." 15

African scholars, sensing the methodological limitations and ideological bias inherent in Eurocentric Teleologism, have forcefully interrogated it. Ake observes: "over the last three decades, [Two-Thirds World or African] countries have become increasingly assertive of their interests and have struggled against colonialism, imperialism and underdevelopment. Their assertive presence and their potential for affecting the equation of power in the modern international system have caused Western scholars to pay attention to them. This attention has been manifest in the rapid growth of development studies." 16

This paper interrogates the Eurocentric view which disregards the formality of Africa's pre-colonial system of education simply because it is erroneously perceived as lacking a Western structure of knowledge production. Moreover, Western social scientists' projection of capitalism as the ideal economic ideology for almost all nations has been questioned against the backdrop of the anti-developmental nature of unbridled capitalism.

\section{Debate on the identity of traditional education in the Pre-colonial Africa}

Africa's system of education prior to the emergence of the European-styled system of education is contextually described as pre-colonial, traditional or informal education. Its main emphases included the learner's adherence to the cultural values of the African people. These values could "be extracted from the beliefs, practices, institutions, myths, folktales and proverbs [of the African people]." ${ }^{17}$ Olupona apparently corroborates Gyekye's opinion by situating the African's pre-colonial identity in the context of religious humanity. The pre-colonial era of Africa was characterized by "various forms of ethnic indigenous religions [which] spread across the African Continent, [and provided] cohesive foundations of nations, peoples, and religious worldviews." 18

Despite the fact of Africans' acquaintance with education since time immemorial, the view was once held by some foreign writers (for example, James George Frazer and Edward B. Tylor) that before the introduction of western education in various African countries, communities on the continent had no form of education. ${ }^{19}$ Undoubtedly, the word "education" was being employed in a rather restricted context to refer to the use of the organized system of education in Europe to train individuals. Those who had been so trained were regarded as the educated. Social scientists (for example, Walter Rodney), however, maintain that generally, education permeates every context and ideology of human endeavour - capitalist, socialist or

\footnotetext{
${ }_{12}$ Claude Ake, "Social Science as Imperialism" in Lauer and Anyidoho (eds.) Reclaiming the Human Sciences and Humanities through African Perspectives, Vol. I (Accra, Ghana: Sub-Saharan Publishers, 2012), 1-30.

13 Ake, "Social Science as Imperialism,"1.

14 Ake, "Social Science as Imperialism," 1-2.

15 Ake, "Social Science as Imperialism," 2.

16 Ake, "Social Science as Imperialism," 2.

${ }^{17}$ Kwame Gyekye, African Cultural values: An Introduction. (Ghana: Sankofa Publishing Company, 2003), xiii.

18 Olupona, “African Humanity Matters: Religious Creativity and Africa’s World Encounters,” 4.

19 Olupona, “African Humanity Matters: Religious Creativity and Africa’s World Encounters,” 4.
} 
communist. ${ }^{20}$ In the view of these social scientists, every community develops its unique educational system that is intended to train individuals to become responsible men and women in the society. Thus Ghanaians had their own traditional ways of training individuals long before their encounter with the European formal school system. These Ghanaian indigenous ways of educating individuals emphasized, among other things, values, beliefs, ideals and precepts.

In their reflections on "the purpose and principles of indigenous education in pre-colonial Africa", Augustus A. Adeyinka and Gaolekwe Ndwapi indicate that the traditional education system of training in Africa prior to colonization generally focused on the learners' acquisition of relevant life skills. Thus in their opinion, "the role of [indigenous] education was to train young people for their sex roles; to inculcate into them a feeling of belongingness and interdependence between all members of the community; to mould their morals and character in a socially acceptable manner; and, finally, to equip them with the skills needed to engage themselves in various occupations satisfactorily. African traditional education thus produced men and women of good character, well rounded individuals who were able to fit into their society." ${ }^{21}$

In fact, one of the essential components of the indigenous system of education, according to Rodney, had to do with its incomparable importance: These characteristics of the traditional system of training are considered to be exceptional: "its close links with social life, both in a material and spiritual sense; its collective nature; its many-sidedness; and its progressive development in conformity with the successive stages of physical, emotional and mental development of the child." 22

In spite of these features, traditional education is said to be unstructured. Hama distinguishes Western or formal education from informal education and characterizes the latter as not structured or systemized and the former as structured or organized. ${ }^{23}$ In the author's opinion, this classification is overtly contentious since some aspects of the traditional system of education were (and still are) formal and therefore structured. The import of this statement is that prior to colonization in Africa, there were defined activities and their corresponding functionaries. In Ghana, for example, initiation ceremonies which were (and still are) integral parts of the traditional system of education took place within the context of a well-structured and harmonized relationship between the children to be initiated and their parents. ${ }^{24}$

The traditional system of education in pre-colonial Africa had its own unwritten curriculum. Olupona points out that "based on sacred narratives, these traditions espoused their unique worldviews. They defined cosmology, ritual practices, socio-political framework, and ethical standards, as well as social and personal identity." ${ }^{25}$ Knowledge production in pre-colonial Africa sought to create a balanced individual thoroughly immersed in their religio-cultural values and institutions.

In terms of the functions of education: "preservation of culture and transformation of culture,"26 there is no distinction between formal and traditional or informal education. They both work toward the same end. The distinction between the two systems of education may be a methodological one. Western scholars' appropriation of enlightenment hermeneutic categories such as rationality and empiricism form the content, concept and context of western knowledge production. To that extent, any knowledge that lacks rational and empirical verification (that is, knowledge defined by western intellectual constructs) could scarcely be judged as authentic and worth pursuing. ${ }^{27}$ On the basis of this, traditional education was not thought to be worth engaging because it was erroneously considered by European scholars such as James George Frazer (18541941) and Edward B. Tylor (1832-1917) to lack the central indicators of western scholarship. As a result, Olupona articulates that Frazer (1854-1941) and Tylor (1832-1917) denied the agency of African religions which form part of the traditional system of education. These European scholars stereotyped African religion

\footnotetext{
20 Abosi and Brookman-Amissah, Introduction to Education in Ghana.

21 Augustus A. Adeyinka and Gaolekwe Ndwapi, "Education and Morality in Africa" Pastoral Care (2002), 3.

22 Walter Rodney, How Europe Underdeveloped Africa (London: Bogle-L'Ouverture Publications, 1976), 262.

23 Hama, The School Curriculum.

${ }^{24}$ Peter Sarpong, Ghana in Retrospect: Some Aspects of Ghanaian Culture (Accra: Ghana Publishing Corporation, 2006$), 73$.

${ }_{25}$ Olupona, “African Humanity Matters: Religious Creativity and Africa’s World Encounters,”.4.

${ }^{26}$ Hama, The School Curriculum, 14.

27 The author is of the view that these features of western scholarship partly express the general problems of methodological and ideological bias in western social science. For a detailed discussion, see Claude Ake, 'Social Science as Imperialism' in Lauer and Anyidoho (eds.) Reclaiming the Human Sciences and Humanities through African Perspectives, Vol. I (Accra, Ghana: Subsaharan Publishers, 2012), 1-30.
} 
- and Africans themselves - as primitive social forms, part of a lower social order. ${ }^{28}$

But the fact that traditional education does not appropriate western intellectual constructs does not mean that it is not worth pursuing. It has been said that "in Africa [traditional educational or] philosophical ideas are not to be found in documents, for traditional African [education] or philosophy is not a written philosophy, although this does not mean that it cannot be written down. Such ideas were embodied in proverbs, aphorisms, or fragments... Yet this fact does not in any way imply the non-existence of [traditional education] or African philosophy." 29

\section{Western Education and the Paradigmatic shift of Ghana's Economic System}

The post-colonial debates on the influence of western education in Africa in general and Ghana, in particular, seem silent or oblivious about western education's influence in gradually changing the economic ideology of Ghana from a mixed and socialist economy to a capitalist mode of production. ${ }^{30}$ To facilitate a better comprehension of the discussion, the article undertakes a cursory survey of these three modes of production or developmental principles: mixed economy, socialist economy and capitalist economy.

A mixed economy is a developmental principle or economic system which integrates the features of both socialism and capitalism. Ghana's identity as a mixed economy has been noted by Yuri Smertin. He indicates that when Ghana attained independence in 1957, the leaders set about to determine the country's path of development through socio-economic reform and the adoption of an effective theoretical foundation. There were two main development paradigms at that time (that is, socialism and capitalism), but Kwame Nkrumah supposed that Africa, and for that matter, Ghana did not need to choose between them. Rather, it had to search for a system of its own which would make use of the best that capitalism and socialism had to offer. ${ }^{31}$ The implication is that Nkrumah sought to pursue a mixed economic policy in which the basic questions undergirding the economic system such as what goods and services are to be produced and for whom to produce those goods and services are addressed by the government, individuals and private firms.

A Socialist economy is a developmental ideology geared towards equity and the sharing of the wealth of the society. ${ }^{32}$ What it means is that in a socialist economy the central economic questions of what goods and services are to be produced and for whom to produce those goods and services - that is, the means of actualizing human development - are all addressed by the government through a central planning authority. Economists maintain that in a command or socialist economy, the allocation of resources such as land and capital is done by a state agency. In that economy, the state is the owner and controller of vital means of production. Under this system, the public sector is the main arbitrator of access to society's resources. ${ }^{33}$ Examples of socialist economies are China, Great Britain, Canada, France and Greece. ${ }^{34}$ Generally, there are three distinct features of socialist economies: Government possession of some of the factors of production, ${ }^{35}$ a greater proportion of decision-making by the state and the existence of a major income redistribution policy meant to bridge the gap between the rich and the poor. ${ }^{36}$ The welfare of the poor, the vulnerable and the deprived is presumed to be enhanced in a socialist economy. In the Marxist taxonomy of the stages of development, socialism was predicted to be the stage where there would be no inequality in the economy. ${ }^{37}$

${ }_{28}$ Olupona, “African Humanity Matters: Religious Creativity and Africa's World Encounters," 4.

${ }^{29}$ Kwame Gyekye, African Philosophical Thought: The Akan Conceptual Scheme (Revised Edition) (Philadelphia: Temple

University Press, 1995), 10.

30 Ewout H.P. Frankema, "The origins of Formal Education in Sub-Saharan Africa: Was British rule more benign? in European Review of Economic History 16 (2012), 2335-355, accessed May 6, 2015. http://www.jstor.org/stable/41708735; Rose B. Folson, "Educational Viability and Development: A Sub-Saharan Experience" in The Journal of Educational Thought (JET) 40 (2006), 75-94 and Damtew Tefera \& Philip Altbach, “African Higher Education: Challenges for the $21^{\text {st }}$ Century" in Higher Education. 47 (2004),21-50, accessed May 6, 2015. Available at http://www.jstor.org/stable/4151555

31 Yuri Smertin, Kwame Nkrumah (Moscow: Progress Publishers, 1987), 120-121.

${ }^{32}$ Kwadwo Asenso-Okyere, Wealth Accumulation, Utilization and Retention (Accra, Ghana: Ghana Universities Press, 2001$), 1$.

33 Philip Hardwick, Bahadur Khan and John Langmead, An Introduction to Modern Economics (England: Addison Wesley Longman Limited, 1994), 4.

34 Stephen L. Slavin, Economics (New York: McGraw Hill/Irwin, 2005), 85.

35 Means of production refers to the factors used to produce goods and services. These factors include land, labour, capital, entrepreneurship and technology.

36 Slavin, Economics, 85.

37 Rodney, How Europe Underdeveloped Africa, 14. 
Even though after independence Ghana opted to pursue a mixed economic ideology, available records indicate that Dr. Kwame Nkrumah had a preferential option for socialism. At the inauguration of the Institute of African Studies at the University of Ghana on October 25, 1963, Dr. Nkrumah said this, among other things: "and in Ghana, the fact that we are committed to the construction of a socialist society makes it especially necessary that this Institute of African Studies should work closely with the people - of Ghana, of Africa and of the world." 38

Moreover, during his tenure of office as the first president, Dr. Kwame Nkrumah saw Ghana as a socialist country. He was reported to have declared on Thursday, March 5, 1964: "Socialism is the goal of the people; no one can stop us." ${ }^{39}$ The president further indicated that "nobody could reverse the verdict of the people in choosing a socialist society, either by violence, silent resistance, sabotage or the wickedness of hidden persuasions." 40 He preferred socialism to other economic ideologies because in his opinion socialism promoted loyal citizenship, a community of equals, a security-conscious community and a people who eschew robbery and hatred. ${ }^{41}$

Under capitalism, "productive resources are owned by individuals and firms. These individuals and firms are looked up to as the engine of growth in the economy with the government playing a facilitating role. The standard of living of individuals depends upon their initial endowments and their productive capacity." 42 Property laws give the owners of resources the right to make decisions concerning access to these resources and to determine the purpose for and the manner in which they are to be used. ${ }^{43}$ In a capitalist development ideology, the basic questions about goods and services to be produced are handled by the invisible hand called the profit motive ${ }^{44}$ or price mechanism. ${ }^{45}$ Countries where the majority of firms and other resources are privately owned and controlled, for instance, Japan and the USA, are, to a large extent, capitalist economies. Owing to the dominance of the private sector in capitalist economies, human development mainly thrives on the quantity of resources individuals own and the preparedness of those wealthy individuals (resource owners) to engage the resources in productive economic activities. As the owners of productive resources produce goods and services, employment and income levels increase. Given the stable socio-political and macroeconomic indicators ${ }^{46}$ in such economies, workers' standard of living increases, and hence improvement in their material conditions.

It must be noted that Western knowledge production, especially social science, is heavily biased in favour of capitalism. ${ }^{47}$ Social science, like any other scientific discipline, emerges from a certain cultural setting or a system of knowledge creation. Scientific research in almost all societies is usually tailored to satisfy the aspirations and concerns of the influential people who normally fund the research, thereby determining and prioritizing nations' goals and regulating the mass media, etc. In the light of this, it would be questionable if Western social science were not intentionally skewed or prejudiced in favour of the upholding of the status quo and the free-market ideology. ${ }^{48}$ Western education's influence in the promotion of capitalist mode of production in Africa and Ghana may also be seen in the upsurge of free-market organizations in most tertiary educational institutions in Africa / Ghana. One of such organizations is Students in Free Enterprise (SIFE). It is an international organization of students who believe in the free-market or capitalist ideology.

\footnotetext{
${ }^{38}$ For details of Dr. Kwame Nkrumah's Address during the opening of the Institute of African Studies, University of Ghana, see Kwame Nkrumah, "The African Genius" in Lauer and Anyidoho (eds.) Reclaiming the Human Sciences and Humanities through African Perspectives, Vol. II, (Accra, Ghana: Sub-Saharan Publishers, 2012), 909-917.

${ }^{39}$ Kwame Nkrumah, "Socialism is the goal of the people, no one can stop us" in The Editors, Jubilee Ghana: A 50- Year News Journey thro' Graphic (Accra, Ghana: Graphic Communications Group Ltd, 2006), 86.

40 Nkrumah, "Socialism is the goal of the people, no one can stop us", 86.

${ }^{41}$ Nkrumah, "Socialism is the goal of the people, no one can stop us", 86.

42 Asenso-Okyere, Wealth Accumulation, Utilization and Retention, 1.

43 Asenso-Okyere, Wealth Accumulation, Utilization and Retention, 1.

44 The concept of The Invisible Hand was coined by Adam Smith, Scottish professor of philosophy. For further reading on this concept, see Adam Smith, Wealth of Nations, Book IV (London: Methuen, 1950), 477-478.

45 Price mechanism simply refers to the interaction of the forces of demand and supply to determine the prices of goods and services in a Capitalist or Free Market Economy. Profit motive and price mechanism are used interchangeably.

46 These socio-political and macro-economic indicators include political stability, respect for fundamental human rights of people, low level of urbanization, low level of inflation, low level of interest rate, etc.

47 Ake, "Social Science as Imperialism," 6-8.

48 Ake, "Social Science as Imperialism," 6-8.
} 
But the question is: what is paradoxical about Western education's influence in promoting a paradigmatic shift in Ghana's economy from mixed and socialist to capitalist economy? In the first place Western education, in pursuance of what Ake refers to as "Eurocentric Teleologism"49 and "the capitalist bias" ${ }^{50}$, seeks to "modernize" Africans to conform to Western standards of development, ideals and values. ${ }^{51}$ Modernization theory, in the thinking of Wayne G. Bragg, assumes that foreign aid stimulates progress. Commenting on the detrimental effects of foreign aid on the recipient countries, Bragg observes that:

In the United States, the U.S. Agency for International Development (USAID) was conceived as a mechanism to transfer technology and foster institutional growth in the [two-thirds world]. In actual fact the aim of foreign aid was much more self-seeking. Richard Nixon put it baldly in 1968 when he said, "let us remember that the main purpose of American aid is not to help other nations but to help ourselves." Eugene Black, former president of the World Bank expands on this theme: "(1) Foreign aid provides a substantial and immediate market for United States goods and services. (2) Foreign aid stimulates the development of new overseas markets for United States companies. (3) Foreign aid orients national economies toward a free enterprise [or capitalist] system in which United State firms can prosper. $^{52}$

The above quotation indicates the exploitative nature of foreign aid which is unquestionably undergirded by capitalist ideology. Ghana's development history indicates the dominance of foreign aid given her "by the Bretton Woods institutions, the World Bank and the International Monetary Fund (IMF)." 53 Education that promotes a system of exploitation scarcely finds a place among Africans or Ghanaians who, ideally, live in a communal context characterized by "communal values such as sharing, mutual aid, caring for others, interdependence, solidarity, reciprocal obligation and social harmony." ${ }_{54}$ Under normal circumstances, these communal values are expressed in the socialist mode of production. Western knowledge production that ends up promoting a system of exploitation results in what Nketsia V refers to as "mis-education." 55 In his understanding, "one is mis-educated if one's education betrays one's cultural identity. The moment African people are educated outside the scope of their indigenous cultural reality, they become ignorant of their actual responsibilities to themselves, their communities and their environment." ${ }^{56}$ If education is generally to help ensure stability and development in the society by preserving and transforming culture, ${ }^{57}$ then Western education becomes a paradox if it stimulates a system or ideology (such as unbridled capitalism) that disintegrates culture. What is the place and relevance of African humanities in the foregone discussion about the paradox of Western education in Ghana?

\section{African humanities and the paradox of Western education in Ghana}

African humanities, as has already been indicated elsewhere in this paper, refer to the arts of Africa which promote individual African's comprehension of the traditions, standards, socio-economic and religio-cultural ties that define people as Africans. ${ }^{58}$ They are expressed in songs, proverbs, maxims, myths, folktales, beliefs and practices of the African. It is important that African humanities respond to the key issues of the identity of traditional education and Western education's role in spearheading a paradigmatic shift of Ghana's economic ideology.

49 Ake, "Social Science as Imperialism," 1.

50 Ake, "Social Science as Imperialism," 1.

51 Nana Kobina Nketsia V African Culture in Governance and Development: The Ghanaian Paradigm (Cape Coast: UCC Press, 2013), 122-135.

52 Wayne G. Bragg, "From Development to Transformation" in Vinay Samuel and Chris Sugden (eds.) The Church in Response to Human Needs (United Kingdom: William B. Eerdmans Publishing Company, 1987), 20-47.

53 Agnes Atia Apusigah, “On Ghanaian Development: Technical Versus Street Evidence” in Lauer and Anyidoho (eds.) Reclaiming the Human Sciences and Humanities through African Perspectives, Vol. I, (Accra, Ghana: Sub-Saharan Publishers, 2012), 388-400.

54 Gyekye, African Cultural Values, 35.

55 Nketsia V, African Culture in Governance and Development, 122.

${ }_{56}$ Nketsia V African Culture in Governance and Development, 122.

57 Hama, The School Curriculum, 14.

58 Nkrumah, "The African Genius," 914. 
However, collective efforts at promoting traditional education in Ghana are pivotal as far as measures to address the paradox of Western education in Ghana (as noted in this paper) are concerned. The apparent success of Western education in shifting, if not obliterating, Ghana's mixed economic and socialist ideologies to capitalist ideology (with its unbridled perils of exploitation), to some extent, underscores Ghana's weaker hold on her indigenous or traditional education. Ghana's firmer grip on traditional education is tantamount to her firmer grip on her cultural consciousness. Cultural consciousness is "a construct that represents the ability of [Ghanaians] to know, perceive, understand and be aware of self in relation to self and all else ... At the most fundamental level, consciousness is found in the pulse that gives us life." 59 The prevalence of the ethics of generosity and fellow-feeling within the indigenous Ghanaian community is anti-exploitative. Such values undoubtedly go a long way to define Ghanaians and their identity.

In the light of this, this paper suggests that all the stakeholders in the provision of education in Ghana - parents, guardians, teachers, students, and the government - should consciously place a premium on traditional education as on Western education. The implication is that there should be a meaningful synthesis of the best aspects of both Africa's traditional system of education and Western education. Consequently, the sound moral training espoused by the pre-colonial system of education in Africa may be realized. ${ }^{60}$ Thus the defunct non-formal education system in Ghana should, as a matter of urgency and policy, be intentionally revamped. This would contribute to the attainment of "African educational ends [which highlight] the community's customs, the acquisition of moral personhood, work-based learning as preparation for work that supports the community and its development, and dialogue." 61

Vernacularization - an intentional educational policy aimed at promoting the use of "first language in the education of children in multilingual Ghana" - should be reinvented. ${ }^{62}$ The general agreement among scholars who have engaged in systematic research on the role of language in education reveals that in multilingual communities such as Ghana, the first language (L1) should be given an important place in the education of children during their formative years, despite some practical challenges that usually characterize such a venture. ${ }^{63}$

The reasons assigned to the re-invention of L1 as the language of instruction in primary levels 1-3 (P1P3) include the following: "L1 is a valuable resource in early education; L1 can promote a smooth transition from home to school; L1 is important in cognitive development; L1 facilitates the early acquisition of knowledge; Literacy in L1 facilitates literacy in English." ${ }^{64}$ Parents and teachers should desist from spanking children when they speak vernacular or their mother-tongue.

Educational institutions and stakeholders in education should explore the possibilities of creatively harmonizing traditional and Western systems of education to produce holistic individuals who would excellently exhibit the virtues of hospitality, solidarity, loyalty, hard work, volunteerism, compassion, love, civility, patriotism, communal and national consciousness.

The liberalization of the media in Ghana is an opportunity for media houses to showcase the diversity and richness of traditional education in the country. Folktales, maxims, proverbs, beliefs and their philosophical underpinnings are some of the programmes media houses and educational institutions in Ghana can use to promote traditional education in the country.

\section{CONCLUSION}

This paper has attempted an argument that traditional education occupies a central place in promoting the identity of the Ghanaian. It has been pointed out that traditional education is as formal as Western education. Furthermore, it has shown the extent to which Western education is spearheading a paradigmatic change in

\footnotetext{
59 Nketsia V African Culture in Governance and Development, 194.

60 Adeyinka and Gaolekwe Ndwapi, "Education and Morality in Africa," 3.

${ }^{61}$ Penny Enslin and Kai Horsthemke, "Philosophy of Education: Becoming Less Western, More African?” Journal of Philosophy of Education, Vol. 50 (2016), 179.

62 Akosua Anyidoho, "First Language in the Education of Children in Multilingual Ghana Revisited" in Lauer and Anyidoho (eds.) Reclaiming the Human Sciences and Humanities through African Perspectives Vol. II (Accra, Ghana: Sub-Saharan Publishers, 2012), 1503.

63 Anyidoho, "First Language in the Education of Children in Multilingual Ghana Revisited," 1503.

64 Anyidoho, "First Language in the Education of Children in Multilingual Ghana Revisited," 1504-1511.
} 
Ghana's economic ideology from mixed and socialist to a capitalist mode of production. The crucial place and relevance of African humanities, especially traditional education, in responding to the paradoxical issues raised in the discussion has been underscored. The effectiveness of African humanities in responding to the issues raised in the paper remains an ongoing epistemological and compelling intellectual project of the scholar of African humanities.

\section{ABOUT AUTHOR}

The Very Rev. Dr. Philip Kwadwo Okyere holds a Bachelor of Arts degree in Economics and Sociology from the University of Cape Coast, Ghana; Bachelor of Divinity degree from Trinity Theological Seminary, Accra, Ghana; Master of Philosophy in the Study of Religions from the University of Ghana; Postgraduate Diploma in Education from the University of Education, Winneba, Ghana, and Doctor of Philosophy in the Study of Religions from the University of Ghana. He is an Ordained Minister of the Methodist Church Ghana and currently an Economics Tutor / Chaplain of Mfantsipim School, Cape Coast, Ghana.

\section{BIBLIOGRAPHY}

Aboagye, Joseph Kingsley, Historical and Philosophical Foundations of Education in Ghana (Winneba: Department of Basic Education, University of Education, Winneba).

Abosi, C.O. and Brookman-Amissah, Introduction to Education in Ghana (Accra: Sedco, 1992).

Adeyinka, Augustus A. \& Gaolekwe Ndwapi, "Education and Morality in Africa", Pastoral Care (2002).

Ake, Claude, "Social Science as Imperialism" in Lauer and Anyidoho (eds.) Reclaiming the Human Sciences and Humanities through African Perspectives, Vol. I (Accra, Ghana: Sub-Saharan Publishers, 2012).

Anyidoho, Akosua, "First Language in the Education of Children in Multilingual Ghana Revisited" in Lauer and Anyidoho (eds.) Reclaiming the Human Sciences and Humanities through African Perspectives, Vol. II (Accra, Ghana: Sub-Saharan Publishers, 2012).

Apusigah, Atia Agnes, “On Ghanaian Development: Technical Versus Street Evidence” in Lauer and Anyidoho (eds.) Reclaiming the Human Sciences and Humanities through African Perspectives, Vol. I (Accra, Ghana: Sub-Saharan Publishers, 2012).

Asenso-Okyere, Kwadwo, Wealth Accumulation, Utilization and Retention (Accra, Ghana: Ghana Universities Press, 2001).

Bragg, G. Wayne, "From Development to Transformation” in Vinay Samuel and Chris Sugden (eds.) The Church in Response to Human Needs (United Kingdom: William B. Eerdmans Publishing Company, 1987).

Enslin, Penny and Kai Horsthemke, "Philosophy of Education: Becoming Less Western, More African?" Journal of Philosophy of Education, Vol. 50 (2016).

Farrant, J. S., Principles and Practice of Education (2 $\left.{ }^{\text {nd }}\right)$ (Singapore: Longman, 1980).

Folson, B. Rose, "Educational Viability and Development: A Sub-Saharan Experience" in The Journal of Educational Thought (JET) 40 ((2006).

Frankema, H.P. Ewout, "The origins of Formal Education in Sub-Saharan Africa: Was British rule more benign? in European Review of Economic History, 16 (2012). Accessed May 6, 2015. http://www.jstor.org/stable/41708735

Graham, C.K., The History of Education in Ghana (Accra: Ghana Publishing Corporation, (1976).

Gyekye, Kwame, African Cultural values: An Introduction. (Ghana: Sankofa Publishing Company, 2003). . African Philosophical Thought: The Akan Conceptual Scheme (Revised Ed.)

(Philadelphia: Temple University Press, 1995).

Hama, Judith, The School Curriculum: A Tool for Education \& National Development (Ghana: Step Publishers, 2004).

Hardwick, Philip, Bahadur Khan and John Langmead An Introduction to Modern Economics (England: Addison Wesley Longman Limited, 1994).

McWilliam, H.O.A and Kwamena-Poh, The Development of Education in Ghana (new ed.) (London: Longman Group Ltd., 1975). 
Monageng, Mogalakwe, "The Documentary Research Method - Using Documentary Sources in Social Research", Eastern Africa Social Science Research Review 25 (2009). Accessed May 6, 2015 http://musejhu.edu/journals/eas/summary/v025/25.1.mogalakwe.html DOI: 10.1353/eas.0.0006

Nancino Brown and Oke F. Brown An Introduction to Methods of Teaching (London: Macmillan Publishers, 1982).

Nketsia, Nana Kobina V African Culture in Governance and Development: The Ghanaian Paradigm (Cape Coast: UCC Press, 2013).

Nkrumah, Kwame, "The African Genius" in Lauer and Anyidoho (eds.) Reclaiming the Human Sciences and Humanities through African Perspectives, Vo II (Accra, Ghana: Sub-Saharan Publishers, 2012). . "Socialism is the goal of the people, no one can stop us" in The Editors Jubilee Ghana: A 50- Year News Journey thro' Graphic (Graphic Communications Group Ltd., 2006).

Nwoye, Augustine, "Remapping the Fabric of the African Self: A Synoptic Theory" in Dialectical Anthropology. 30(2006). Accessed May 6, 2015 http://www.jstor.org/stable/29790757

Olupona, K. Jacob, “African Humanity Matters: Religious Creativity and Africa's World Encounters” in Gordon S.K. Adika, George Ossom-Batsa and Helen Yitah (eds.) New Perspectives on African Humanity: Beliefs, Values and Artistic Expression (Accra, Ghana: Adwinssa Publications (Gh.) Ltd., 2014).

Quist, O. Hubert, "Transferred and Adapted Models of Secondary Education in Ghana: What Implications for Development" in International Review of Education. 49 (2003). Accessed May 6, 2015 http://www.jstor.org/stable/3445308

Rodney, Walter, How Europe Underdeveloped Africa (London: Bogle-L'Ouverture Publications, 1976).

Sarpong, Peter, Ghana in Retrospect: Some Aspects of Ghanaian Culture (Accra: Ghana Publishing Corporation, 2006).

Slavin, L. Stephen, Economics (New York: McGraw Hill/Irwin, 2005).

Smertin, Yuri, Kwame Nkrumah (Moscow: Progress Publishers, 1987).

Tefera, Damtew \& Philip Altbach, "African Higher Education: Challenges for the $21^{\text {st }}$ Century" in Higher Education. 47 (2004).:21-50. Accessed May 6, 2015.http://www.jstor.org/stable/4151555 